\title{
Lessons Learned from Biosphere 2 and Laboratory Biosphere Closed Systems Experiments for the Mars On Earth ${ }^{\circledR}$ Project
}

\author{
Abigail Alling ${ }^{1}$, Mark Van Thillo ${ }^{1}$, William Dempster ${ }^{2}$, Mark Nelson ${ }^{3}$, Sally Silverstone ${ }^{1}$, John Allen ${ }^{2}$ \\ ${ }^{1}$ Biosphere Foundation, P.O. Box 201 Pacific Palisades, CA 90272 USA \\ ${ }^{2}$ Biospheric Design (a division of Global Ecotechnics) 1 Bluebird Court, Santa Fe, NM 87508 USA \\ ${ }^{3}$ Institute of Ecotechnics, 24 Old Gloucester St., London WC1 U.K.
}

\begin{abstract}
Mars On Earth® (MOE) is a demonstration/research project that will develop systems for maintaining 4 people in a sustainable (bioregenerative) life support system on Mars. The overall design will address not only the functional requirements for maintaining long term human habitation in a sustainable artificial environment, but the aesthetic need for beauty and nutritional/psychological importance of a diversity of foods which has been noticeably lacking in most space settlement designs.

Key features selected for the Mars On Earth ${ }^{\circledR}$ life support system build on the experience of operating Biosphere 2 as a closed ecological system facility from 1991-1994, its smaller 400 cubic meter test module and Laboratory Biosphere, a cylindrical steel chamber with horizontal axis 3.68 meters long and 3.65 meters in diameter.

Future Mars On Earth ${ }^{\circledR}$ agriculture/atmospheric research will include: determining optimal light levels for growth of a variety of crops, energy trade-offs for agriculture (e.g. light intensity vs. required area), optimal design of soil-based agriculture/horticulture systems, strategies for safe re-use of human waste products, and maintaining atmospheric balance between people, plants and soils.
\end{abstract}

Key words: agriculture, air, closed system, sustainable

\section{Introduction: The Emergence of Closed Ecological Systems}

New kinds of laboratory and experimental facilities open up new scientific possibilities. Closed ecological systems of varying size and complexity have been developed over the past few decades: from laboratorysized microbial ecosystems to larger systems capable of human life support that contain considerable biodiversity and a variety of ecosystem types. Just as the concept of closure was crucial to the development of classical thermodynamics and physics, the development of closed ecological systems has opened the study of ecosystems and biospheric systems to a truly experimental approach (Morowitz et al, 2005). Figure 1 shows not only the classical approach to closure, but new possibilities due to the addition of information that is gained through the process of creating closed ecological systems.

To date, most closed system research for human life support has focused on food production and the recycling of air and water using ecological systems that are reliable and sustainable. Some of the emphasis in bioregenerative technology development has been driven by the need to reduce consumables (such as food which would have

\section{Article ID: 051904035}

Presented at International Conference on Research Highlights and Vanguard Technology on Environmental Engineering in Agriculture Systems, Kanazawa, Japan, September, 2005 to be resupplied at high cost), while at the same time recognizing that sustainable life support systems must be designed to maximize efficiency and productivity in order to keep areas, volumes and energetic requirements at a minimum. For example, at the heart of efforts to replace food consumables for life support, scientists have focused their research on two approaches: those that involve soil-based/traditional agriculture systems as compared with hydroponic/genetically modified crop cultivars.

Closed systems have also been used to study ecological systems with the aim of sustainable development and environmental protection on Earth. An increased awareness of the ecological challenges

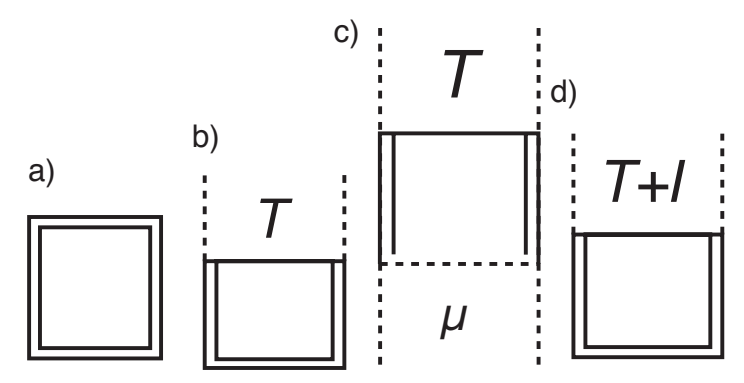

Fig.1. Schematics of differing types of closed systems. a) Complete closure - system closed to the flow of energy and matter (adiabatic walls). b) System open to the flow of energy, but closed materially (diathermal walls). c) System open to the flow of energy and matter. $T$ represents energy, and the symbol $\mu$ (chemical potential) indicates open to the flow of matter. $d$ ) closed ecological systems: open to information (/) and energy ( $T$ ) but essentially closed to material exchange. Examples include the Earth's biosphere, Biosphere 2, CEEF. 
Alling, A. et al.

Table 1 Ratio comparisons of land (soil) surface to water surface, water volume and atmospheric volume.

\begin{tabular}{|l|c|c|c|}
\hline & Earth & Biosphere 2 & Laboratory Biosphere \\
\hline Soil Area: $\mathbf{m}^{2}$ & $1.5 \times 10^{14}$ & 6300 & 5.37 \\
\hline Atmospheric Volume: $\mathbf{m}^{3}$ & $\begin{array}{c}4.3 \times 10^{18} \\
\left({ }^{*} 1\right)\end{array}$ & $\begin{array}{c}\text { Average } \\
180000\end{array}$ & $\begin{array}{c}\text { Average } \\
40\end{array}$ \\
\hline Water Surface/ $\mathbf{~}^{2}$ Land & 2.4 & 0.2 & $0.1-0.6$ \\
\hline Water Volume/ $\mathbf{m}^{2}$ Land & $\begin{array}{c}8300 \\
\left({ }^{*} 2\right)\end{array}$ & 0.9 & 0.07 \\
\hline $\begin{array}{l}\text { Atmospheric Volu me/ } \mathbf{m}^{2} \\
\text { Land }\end{array}$ & $\begin{array}{c}\sim 29,000 \\
\left({ }^{*} 1\right)\end{array}$ & 29 & 6.8 \\
\hline Leak Rate & Negligible input or loss & $<10 \% /$ year & $1 \% /$ day \\
\hline
\end{tabular}

${ }^{*} 1$ = Equivalent at standard pressure, $15^{\circ} \mathrm{C} ;{ }^{*} 2$ = Assuming average ocean depth of $3400 \mathrm{~m}$

facing humanity - global warming, industrial pollution, loss and degradation of natural ecosystems, species extinctions and reliance on finite resources such as nonrenewable fossil fuels - has led to dramatically changed perceptions with regards to our global biosphere. These perspectives on how to live sustainably with the Earth' $\mathrm{s}$ biosphere have many similarities with the objectives of creating man-made biospheres and bioregenerative life support systems for space. Bioregenerative life support systems developed for small, partially or fully materially closed ecosystems will provide new data and incentives for Earth-based applications that will encourage a shift from the destructive mindset of "unlimited resources" to that of conserving, recycling and sustainably managing limited resources. The concept of "zero-emission" as a goal for industry reflects this change of thinking.

Previously, pollution has been viewed as an inevitable by-product of the human economy with negative impacts on local ecosystems and the global biosphere. Now, just as in a man-made closed ecological system, the challenge of industrial waste is to maximize recycling between and within processes, to reduce or replace non-recyclable or toxic compounds, and to develop bioremediation to safeguard the environment. In any closed system of whatever scale, there is no "away." Closed artificial systems offer an extremely useful laboratory environment for the study of complex systems. Small scale man-made closed ecological systems, combined with their differing ratios of soil, water and atmosphere (compared with our global biosphere) accelerate the rate of elemental cycles. This provides a laboratory that puts their relationships, so to speak, under a time microscope. Table 1 presents such a comparison between the Earth (Biosphere 1), Biosphere 2, and Laboratory Biosphere closed ecological systems.

Depending on the system's size and its ratio of components, each closed ecological system has unique "metabolic" characteristics (Table 2). This presents both a challenge on how to properly manage and balance biogeochemical cycles inside closed ecological systems, as well as an opportunity because they offer a superb experimental tool for investigation of such cycles. They open up the potential for "comparative biospherics" as a way of gaining insight into Earth's biosphere; just as

Table 2 Estimates of carbon ratios in biomass, soil and atmosphere in the Earth's biosphere, Biosphere 2 and the Laboratory Biosphere facility and an estimate of carbon cycling time as a consequence (data from Bolin and Cook, 1983; Dempster et al, 2004; Nelson et al, 2003a; Schlesinger, 1991).

\begin{tabular}{|l|c|c|c|}
\hline & Earth & Biosphere 2 & Laboratory Biosphere \\
\hline $\begin{array}{l}\text { Ratio of Biomass C: } \\
\text { Atmospheric C }\end{array}$ & $\begin{array}{c}1: 1 \\
\left(\text { at } 350 \mathrm{ppm} \mathrm{CO} \mathrm{CO}_{2}\right)\end{array}$ & $\begin{array}{c}100: 1 \\
\left(\text { at } 1500 \mathrm{ppm} \mathrm{CO} \mathrm{CO}_{2}\right)\end{array}$ & $\begin{array}{c}\text { (mature crop to atmosphere at } \\
\left.1500 \mathrm{ppm} \mathrm{CO}_{2}\right)\end{array}$ \\
\hline $\begin{array}{l}\text { Ratio of Soil C: } \\
\text { Atmospheric C }\end{array}$ & $2: 1$ & $5000: 1$ & $\begin{array}{c}1650: 1 \\
\left(\text { atmosphere at } 1500 \mathrm{ppm} \mathrm{CO}_{2}\right)\end{array}$ \\
\hline $\begin{array}{l}\text { Estimated C } \\
\text { Residence Time in } \\
\text { Atmosphere }\end{array}$ & 3 years & $1-4$ days & $0.5-2$ days \\
\hline
\end{tabular}

Note: Biosphere 2 biomass to atmosphere carbon ratio is 100:1 if dry weight of biomass is 27 metric tons. Laboratory Biosphere atmospheric carbon is about 20 grams at 1500 ppm. Ratios $96-280$ would be for biomass of $4.8 \mathrm{~kg}$ to $14 \mathrm{~kg}$ dry weight. For Laboratory Biosphere, the ratio soil C to atmosphere C calculated using January 2003 analysis with $5 \%$ organic matter in soil. 
comparative planetology has provided insight into the dynamics of our home planet.

\section{Biosphere 2}

The Biosphere Consortium (Biosphere Foundation, Biospheric Design and Institute of Ecotechnics) has two decades of experience with the design and research of closed ecological systems using the Biosphere 2 Test Module (1986-1989), Biosphere 2 (1990-1994), and the Laboratory Biosphere (2002-present). This know-how is now being applied to the design for a future project called Mars On Earth ${ }^{\circledR}(\mathrm{MOE})$.

\subsection{Biosphere 2 Test Module}

The Biosphere 2 Test Module is a $400 \mathrm{~m}^{3}$ materiallyclosed ecological facility, the largest such facility built prior to the completion of Biosphere 2. It was designed to test both the engineering and structure planned for the much larger Biosphere 2, and life system interactions in conditions of a closed ecological system. In operating the testbed, there were progressive approximations made towards creating and operating a successful integrated life support system. For example, initial experiments included the testing of two sealing methods, several generations of analytic/sensor systems and the first application of the variable volume chamber concept. The Biosphere 2 Test Module was sealed underground with a steel liner and was connected via an air duct with a variable volume chamber (lung). This "lung" allowed the atmosphere to expand and contract without exerting force on the facility's structure. The Biosphere 2 Test Module achieved a leak rate of $24 \%$ per year (Nelson et al, 1992) and it was the first bioregenerative facility to achieve air purification through biological means (vs. catalytic burners), water cycling, and human waste and domestic gray water waste recycling. Food was grown to supply nutrition during the short-term human closures, but the limited growing area was not adequate to support long periods of human habitation. Over 60 person-days were logged in experiments, including a three-week closure in November 1989 (Alling et al, 1993, Alling et al, 1990; Nelson et al, 1992).

\subsection{Biosphere 2 Overview}

Biosphere 2, a 1.27 hectare system, was the first system designed with a diversity of biomes/ecosystem types (Fig. 2), thus making it a laboratory for study of the Earth's biosphere as well as a facility for the development of bioregenerative technologies for human life support (Allen et al, 2003; Allen, 2000; Allen and Nelson, 1999). The first Biosphere 2 experiment, 1991 - 1993, was an excellent prototype for a manned space mission: eight people lived for two years in a man-made biosphere. All of the water and wastewater was recycled, air was recycled and purified (there was an addition of oxygen which will be discussed below), and $81 \%$ of all the food for the two-year mission was grown inside (the remaining $19 \%$ was supplied with seed stock and food

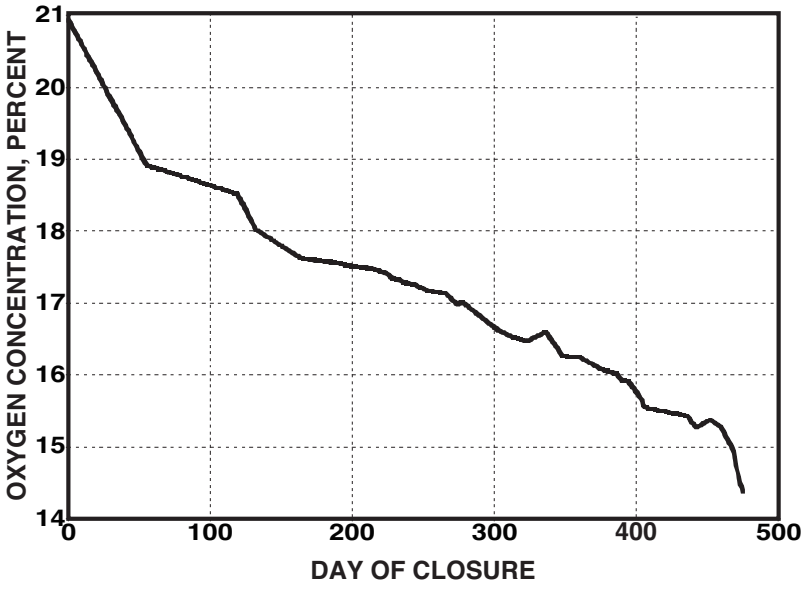

Fig. 2. Schematic layout of Biosphere 2 showing the human habitat, intensive agriculture, natural biome analogues, variable pressure facilities (lungs) at the facility, Oracle, Arizona. The airtight footprint of Biosphere 2 was 1.27 hectares and overall volume around $200,000 \mathrm{~m}^{3}$. It was operated as a closed ecological system from 1991-1994.

grown inside the system prior to closure). Observations of the group dynamics and human health during the two years also provided invaluable information with regards to designing biospheric systems for long-term space missions (Allen, 2002; Alling et al, 2002). This was a major factor in the Biosphere 2 design - systems were designed to be safe, reliable and efficient as well as satisfying and aesthetically pleasing for its inhabitants. While crews have survived in submarines, cramped space stations and underground isolation chambers for periods of months to years, these types of sterile and mechanical environments are hardly conceivable as permanent habitations for people. There are also significant concerns about the long-term reliability and stability of such systems if they are to be used in space, outside the safety net of the Earth's biosphere.

Biosphere 2 was also a laboratory for the study of global ecology where the dynamics and operational characteristics of large and complex ecological systems could be studied from microbial diversity to the scale of biogeochemical cycles and global changes, from genetics to population dynamics. It was an unprecedented attempt to both further the study of the biosphere and develop sustainable systems for Earth. Recognizing that Earth (Biosphere 1) is an amazingly successful closed ecological system, the builders of Biosphere 2 incorporated many aspects of Earth's biosphere into, by comparison, the tiny Biosphere 2. Biosphere 2's design included analogues of major natural biomes such as rainforest, savannah, ocean, desert and marsh, plus two anthropogenic biomes, agriculture and human habitat (Fig. 2). Overall there were some 3800 species of plants and animals. 


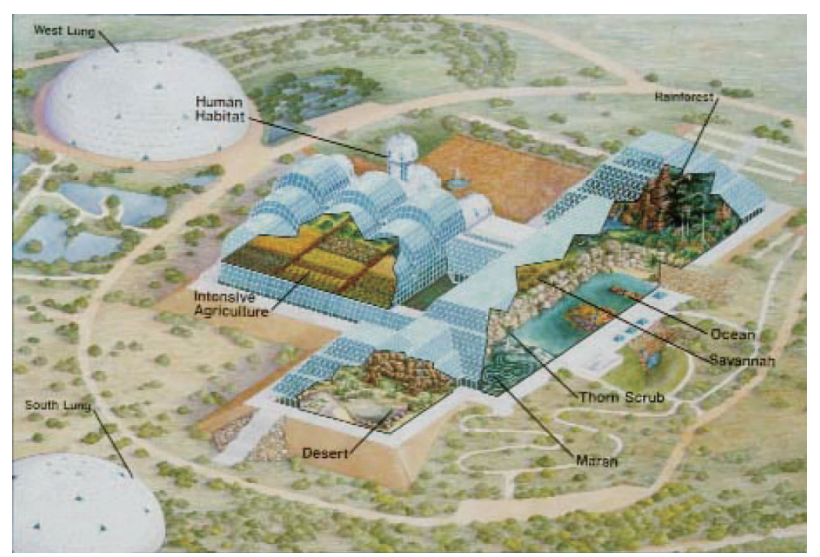

Fig. 3. Oxygen concentration in Biosphere 2 September 26, 1991 - January 13, 1993.

\subsection{Oxygen Dynamics in Biosphere 2}

A central feature of Biosphere 2, which makes many of the observed data particularly meaningful, was its high degree of closure. Degree of closure must be such that its leak rate is slow compared to internal processes so that the leakage has negligible effects on those internal processes (Dempster, 1994). Biosphere 2 achieved a leak rate of less than $10 \%$ per year. The significance of this is dramatically illustrated by changes of oxygen concentration over a period of 475 days (Dempster, in press).

Figure 3 shows oxygen concentration from September 26, 1991 to January 13, 1993, a period of 1.3 years. Although the declining concentration of oxygen is very slow, averaging only $140 \mathrm{ppm} \mathrm{d}^{-1}$, the fact that loss can accumulate and reach a large difference from normal oxygen concentration of 20.9 percent allows the process to be accurately measured and studied. In Fig. 4, compare how the decline would have appeared for different hypothetical leak rates of Biosphere 2 as determined by computer simulation. For perfect closure ( $0 \%$ per year), the curve is only slightly different, but at higher leak rates, as are common in many CES test facilities (such as the space shuttle which leaks 1.9 $\% /$ day), it may be difficult to become aware that a loss of oxygen is occurring. A substantial cumulative loss of oxygen in a remote life support system will be life threatening. It is essential that systems developed and tested for future remote missions identify cumulative atmospheric changes that can only be observed when leak rates are very low. Thus for investigation of subtle changes in biogeochemical cycles and atmospheric composition, it is crucial to achieve a high degree of closure or the differences will be undetectable.

\subsection{Carbon Dioxide Dynamics in Biosphere 2}

Fluxes of biogeochemical elements can be rapid in small, closed ecological systems because of the high concentrations of biotic elements, and comparatively

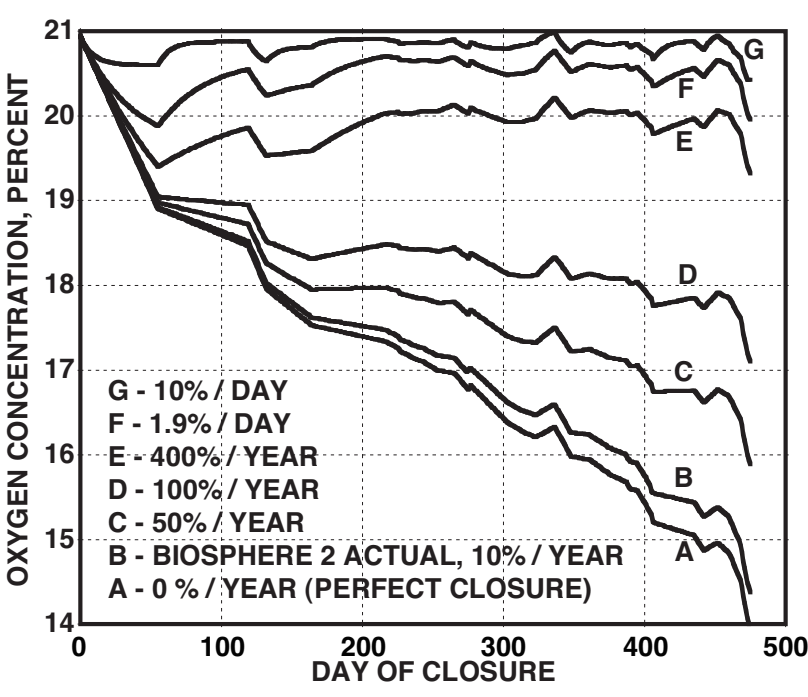

Fig. 4. Oxygen concentration in Biosphere 2, actual and simulated for six other leak rates.

small atmosphere. Even with Biosphere 2's volume of some $200,000 \mathrm{~m}^{3}, 83 \mathrm{~kg}$ of carbon will raise the concentration of $\mathrm{CO}_{2}$ from 350 to $1500 \mathrm{ppm}$ in the facility's atmosphere. Carbon dioxide showed daily fluctuations of 500-600 ppm on a bright sunny day (Fig. 5). This large swing is due to the two orders of magnitude higher ratio of carbon in plant biomass to atmospheric carbon in Biosphere 2 compared to Earth (Table 2) and the active photosynthesis of the vegetation during daylight hours and dominance of plant and soil respiration during dark night time. The large seasonal light variation at the project site in southern Arizona (from 9.5 hours of light in winter to 14.5 hours of sunlight in

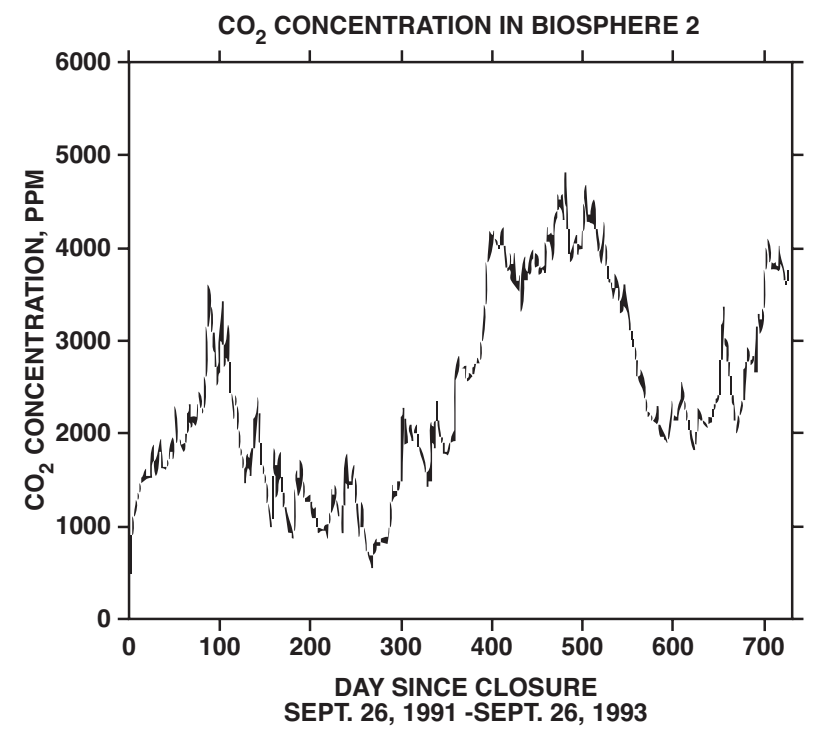

Fig. 5. Carbon dioxide average daily concentration in the Biosphere 2 atmosphere during the two year closure experiment, 1991-1993. 


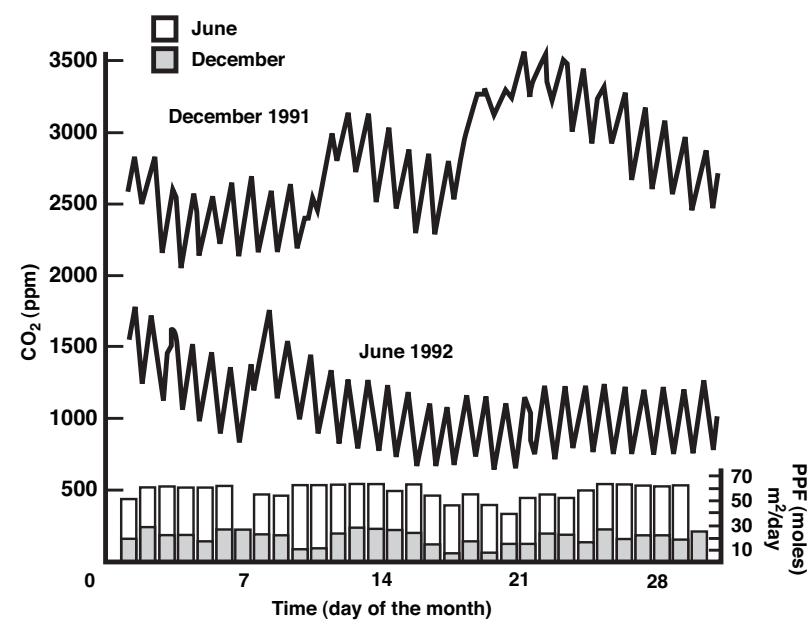

Fig. 6. Day-night oscillation of $\mathrm{CO}_{2}$, about $600 \mathrm{ppm}$, is shown in this graph of a winter (top) and a summer month (lower). The histogram at bottom also shows total daily light for the winter month (shaded bar) and for the summer month (clear bar).

summer) is also reflected in Biosphere 2 carbon dioxide dynamics (Figs. 5 and 6).

Some of the strategies employed for managing $\mathrm{CO}_{2}$ included lowering night time temperatures (which reduces phytorespiration), suspending composting and minimizing soil disturbance during low-light seasons, pruning to stimulate regrowth, and drying of biomass for long-term storage. A physico-chemical precipitator was also installed inside Biosphere 2 and it was used to lower carbon dioxide concentrations by 100 ppm per day when necessary in the winter months (Nelson et al, 1994).

\subsection{Food Production in Biosphere 2}

During the first Biosphere 2 closure experiment from 1991-1993, approximately $81 \%$ of food for the 8 -person crew was grown on the $2000 \mathrm{~m}^{2}$ agriculture system; the remaining $19 \%$ came from seed stock and food previously grown in Biosphere 2 that was replaced over the years through successive harvests. (On year three, $100 \%$ of the food was grown inside.) Productivity was directly related to ambient light levels. Of critical importance was the fact that $50-55 \%$ of the natural Arizona light was removed by the glass space frame (45-50\% reached the Biosphere agriculture system) and the 1991-1993 experiment occurred during two elNino years which caused abnormally low light levels. For example, a wheat crop grown with total light of $679 \mathrm{~mol} \cdot \mathrm{m}^{-2} P P F$ yielded only $40 \mathrm{~g} \cdot \mathrm{m}^{-2}$, while a crop grown with $2022 \mathrm{~mol} \cdot \mathrm{m}^{-2} P P F$ (nearly three times as much light) yielded $240 \mathrm{~g} \cdot \mathrm{m}^{-2}$ or six times as much grain (Silverstone and Nelson, 1994). Experience gained from Biosphere 2's 1991-1993 closure experiment led to improvements that included the addition of some artificial light in the agricultural system that helped make possible the increased yields and $100 \%$ food sufficiency achieved in the second March to September 1994 human closure experiment (Marino et al, 1999).
Over 86 crops (including herbs) were included in the first closure experiment. The diet for the eight crew members of Biosphere 2 included milk (from African pygmy goats) eggs (from the system's domestic chickens), meat (from the goats, chickens and Ossabaw feral pygmy pigs), and fish (from Tilapia grown as in the rice/azolla water fern paddies). A computer program kept track of nutrient intake and helped plan forward planting of crops to ensure a balanced diet. The agricultural area also produced the fodder necessary for the domestic animals as well as direct human food crops. The reliance on ambient sunlight, reduced by $50-55 \%$ in passing through the glazed envelope, limited crop productivity and might differ in space application and other closed ecological systems where advantage may be taken of enhanced artificial light techniques to boost yields and reduce area required for agriculture.

Other variables, apart from reduced light, may have also affected crop productivity in Biosphere 2. These include elevated carbon dioxide concentrations, decreased oxygen during much of the first closure mission, the ratio of direct to diffuse light above the canopy, and the absence of strong winds which impacts plant strength and pollination. These and other differences can be further investigated using facilities like CEEF, Laboratory Biosphere and Mars On Earth ${ }^{\circledR}$ facilities.

Biosphere 2 was the first closed ecological system to use soil as the plant growth media rather than hydroponics. There are a number of reasons for using soil. Since Biosphere 2 was a laboratory for the study of biospherics, the use of soil made systems far more comparable to natural ecosystems on Earth. In addition, buildup of trace gases and pollutants are a major health and operational concern, the intense and diverse microbiological biota within soils purifies air and is critical component of biogeochemical cycles (Alling et al, 1990: Alling et al, 1993, Frye and Hodges, 1990). Soil also simplifies the waste recycling systems for animal and human wastes and inedible portions of crops. Composting and constructed wetlands for biomass reuse and wastewater treatment are far less energyconsumptive than alternatives like wet oxidation or incineration. Agricultural soils, constructed wetlands and compost systems operate by time-tested biological mechanisms. The biomass produced in constructed wetlands can be used for fodder for domestic animals as was done in Biosphere 2, or returned to the soil through composting, thus replenishing the nutrients that crops remove from the soil. Hydroponics, on the other hand, requires a steady supply of chemical nutrients, fertilizers and pesticides that cannot be produced from within the system (Glenn and Frye, 1990, Nelson et al, 1994). Hence, a critical aim for the design of closed ecological systems for life support is not only supply of a complete, nutritionally balanced diet, but the maintenance of sustaining a fertile system. 


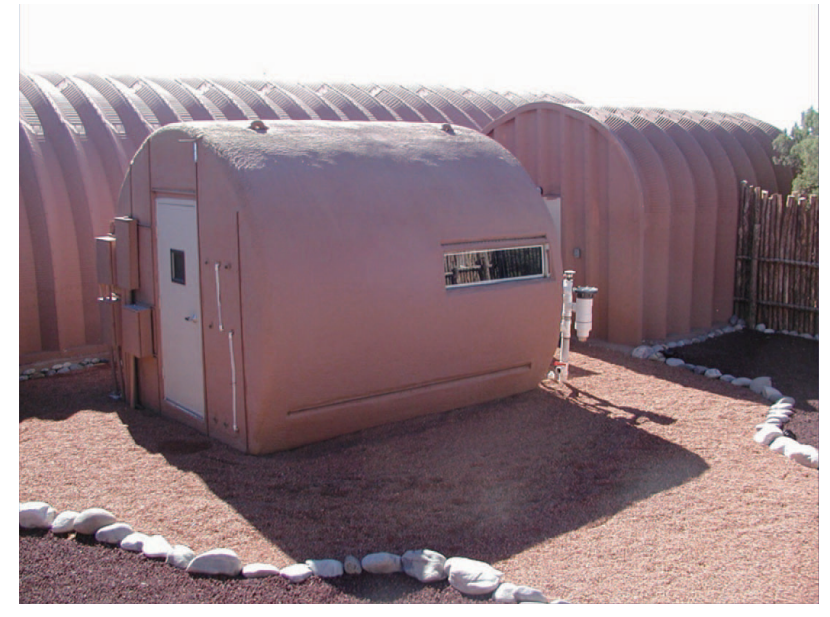

Fig. 7. Laboratory Biosphere Facility, Santa Fe, New Mexico, USA.

An agricultural system in a materially closed system must be virtually pollution-free since air, water and soil buffers are so small and cycling times so rapid. Introducing pesticides and herbicides risks contamination and serious health hazards. With no process to disperse or dilute air and water pollution; it will just appear as a problem "somewhere else". The truth that the "world is our backyard" is immediately obvious in a small closed ecological system, but is only beginning to be understood on a planetary scale. Therefore in place of toxic chemicals, a variety of biological and cultural methods of pest and disease control (known as Integrated Pest Management) must be utilized for the agricultural crops. IPM techniques include: selection of resistant crops, small plots with frequent replantings, switching between several cultivars (varieties) of the major crops, maintenance of "beneficial insect" populations (ladybugs, praying mantis, parasitic wasps etc.) to control pest insects, intercropping and manual control when necessary. In addition "safe sprays" such as soap, light oil or Bacillus thuringensis can be used and were used in Biosphere 2 (Silverstone and Nelson, 1996).

\subsection{Laboratory Biosphere}

Since 2002, a series of closed ecological system experiments has been conducted in the Laboratory Biosphere, a 34-43 $\mathrm{m}^{3}$ closed system (Fig. 7) in Santa Fe, New Mexico, USA. The Laboratory Biosphere was created as a testbed to continue experiments using a sustainable soil based agriculture system, artificial lights and the small volumes of components more suitable for space life support (Nelson et al, 2003b, Dempster et al, 2004). Table 3 summarizes the mass and volume of the components in the
Laboratory Biosphere closed ecological facility. Initial experiments, 2002-2004, used crops of soybeans, dwarf wheat, compact sweet potatoes, pinto bean and cowpea to study biogeochemical cycles, atmospheric dynamics, crop productivity, nutrient recycling, soil fertility, light efficiency and observations of Mir $3^{\text {rd }}$ generation wheat seed.

\subsection{Laboratory Biosphere Food Production}

Interesting observations include the experimentation with sweet potato (TU-82-155) that had a 50\% higher productivity using the soils system than trials using hydroponic methods with the same variety of sweet potato at NASA Johnson Space Center (Barta, 2001; Nelson et al, 2005). The projected yields of sweet potato for the Mars On Earth facility ${ }^{\circledR}$ were initially extrapolated at twice Biosphere 2's best yields of $16 \mathrm{~g}$ $\mathrm{m}^{-2} \mathrm{~d}^{-1}$ (wet weight at $25 \mathrm{~mol} \mathrm{~m}^{-2} \mathrm{~d}^{-1}$ light) or $32 \mathrm{~g} \mathrm{~m}^{-2}$ $\mathrm{d}^{-1}$ (wet) with the $50 \mathrm{~mol} \mathrm{~m} \mathrm{~d}^{-1}$ of light planned for the facility (Silverstone et al, 2003). The experiment in the Laboratory Biosphere at around $44 \mathrm{~mol} \mathrm{~m}^{-2} \mathrm{~d}^{-1}$ light averaged $58.7 \mathrm{~g} \mathrm{~m}^{-2} \mathrm{~d}^{-1}$ (wet) which was therefore $83 \%$ higher than the yield data projected for the MOE facility

Table 3 Summary of light input and results from the wheat and sweet potato experiments in the Laboratory Biosphere.

\begin{tabular}{|c|c|c|}
\hline Laboratory Biosphere Data & Wheat & Sweet Potato \\
\hline $\begin{array}{l}\text { Planting density: plants } / \mathrm{m}^{2} \text {, } \\
\text { East side / West side }\end{array}$ & $400 / 800$ & $16 / 16$ \\
\hline $\begin{array}{l}\text { Light regime hours } \\
\text { on / hours off }\end{array}$ & $16 / 8$ & $18 / 6$ \\
\hline $\begin{array}{l}\text { Light intensity } \\
\mathrm{mmol} \mathrm{m}^{-2} \mathrm{~s}^{-1}\end{array}$ & 840 & 699 \\
\hline $\begin{array}{l}\text { Daily light } \\
\mathrm{mol} \mathrm{m}^{-2} \mathrm{~d}^{-1} \text { (typical) }\end{array}$ & 48.4 & 45.3 \\
\hline Days from planting to harvest & 87 & 126 \\
\hline $\begin{array}{l}\text { Total light } \\
\mathrm{mol} \mathrm{m}^{-2} \text { (actual) }\end{array}$ & 3981 & 5568 \\
\hline $\begin{array}{l}\text { Total dry biomass, g, } \\
\text { East side / West side * }\end{array}$ & $3104 / 4387$ & $6800 / 4907$ \\
\hline $\begin{array}{l}\text { Average dry biomass: } \mathrm{g} \mathrm{m}^{-2} \\
\text { East side / West side }\end{array}$ & $1156 / 1634$ & $2533 / 1828$ \\
\hline $\begin{array}{l}\text { Average dry biomass rate, } \mathrm{g} \mathrm{m}^{-2} \\
\mathrm{~d}^{-1} \\
\text { East side / West side }\end{array}$ & 13.3/18.8 & $20.1 / 14.5$ \\
\hline $\begin{array}{l}\text { Average dry edible, } \mathrm{g} \mathrm{m}^{-2} \\
\text { East side / West side }\end{array}$ & $566.5 / 812.3$ & $1657 / 1202$ \\
\hline $\begin{array}{l}\text { Average dry edible rate, } \mathrm{g} \mathrm{m}^{-2} \mathrm{~d}^{-1} \\
\text { East side / West side }\end{array}$ & $6.5 / 9.3$ & $13.1 / 9.5$ \\
\hline Overall Harvest index & 0.49 & 0.66 \\
\hline $\begin{array}{l}\text { Light efficiency-biomass, g/mol } \\
\text { East side / West side }\end{array}$ & $0.29 / 0.41$ & $0.45 / 0.33$ \\
\hline $\begin{array}{l}\text { Light efficiency, dry edible, } \mathrm{g} / \mathrm{mol} \text {, } \\
\text { East side / West side }\end{array}$ & $0.14 / 0.2$ & $0.30 / 0.22$ \\
\hline
\end{tabular}

*Dry biomass for sweet potato tubers was estimated by drying samples to determine a dry weight to wet weight ratio and multiplying wet weights by the ratio so obtained which was 0.194 . 
(Table 6). This demonstrates the importance of testing crop cultivars and growing conditions in a closed system that is the size, scale and using the proposed engineering systems for a Mars base.

Compared with Biosphere 2 production of wheat at relatively low light $\left(6.4-16.4 \mathrm{~mol} \mathrm{~m}^{-2} \mathrm{~d}^{-1}\right)$, with average wheat production of $120 \mathrm{~g}$ seed $\mathrm{m}^{-2}$, the average production from this study is over 5 times higher, and the best area over 7 times higher. At the highest light in Biosphere 2, $16.4 \mathrm{~mol} \mathrm{~m}^{-2} \mathrm{~d}^{-1}$, yield was $240 \mathrm{~g} \mathrm{~m}^{-2}$ about $1 / 3$ that of the current study; total light was $2022 \mathrm{~mol} \mathrm{~m}^{-2}$ (about half of this study) and light efficiency was 0.12 $\mathrm{g}$ seed/mole, about $30 \%$ less efficient than the wheat crop in the Laboratory Biosphere (Nelson et al, in press: Silverstone and Nelson, 1996).

The projected wheat yields for the MOE facility (Table 5), derived using three times the average Biosphere 2 wheat yields to reflect the increased light levels of 50 mol m $\mathrm{m}^{-2} \mathrm{~d}^{-1}$ planned for MOE were estimated at $7.3 \mathrm{~g} \mathrm{~m}^{-2}$ $\mathrm{d}^{-1}$ (Salisbury et al, 2002; Silverstone et al, 2003). The recent yields in the Laboratory Biosphere $\left(7.9 \mathrm{~g} \mathrm{~m}^{-2} \mathrm{~d}^{-1}\right)$ were thus $8 \%$ better than those projections.

Laboratory Biosphere crop results (Table 3) suggest that soil-based systems are comparable with and sometimes out produce the yield of hydroponic systems which have predominated previous bioregenerative space life support systems. This is significant since soils will reduce dependence on highly technical systems which rely on consumables like hydroponic chemicals as well as provide soil microbiota that will assist in completion of biogeochemical cycles and reduction of problematic trace gases (Alling et al, 1990; Frye and Hodges, 1990; Bohn, 1972). In addition, both the sweet potato and wheat results show that the increase in light provided in the Laboratory Biosphere as compared with Biosphere 2 results in greater yields. This is turn will enable a reduction in space requirements for food production, and support the strategy of increasing light supplied to optimize plant efficiency and productivity (Salisbury et al, 2002).

\subsection{Laboratory Biosphere Atmospheric Dynamics}

On planet Earth humans have the great luxury of nearly invariant atmospheric composition. The opposing processes of photosynthesis by plant life and respiration by animal life (especially soil respiration), as moderated by the biogeosphere as a whole, are so finely balanced with each other that it has required the development of advanced technology within the last century to detect any variations at all. The Biosphere 2 experiment conclusively demonstrated that in small closed systems, the atmosphere was the most dynamic component of the biosphere. And further, that the atmosphere was far more interactive with life in the soil and water then previously understood. Now we contemplate constructing small biospheres that can sustainably support a few humans in food, water and air. To do that, a sufficient approximation
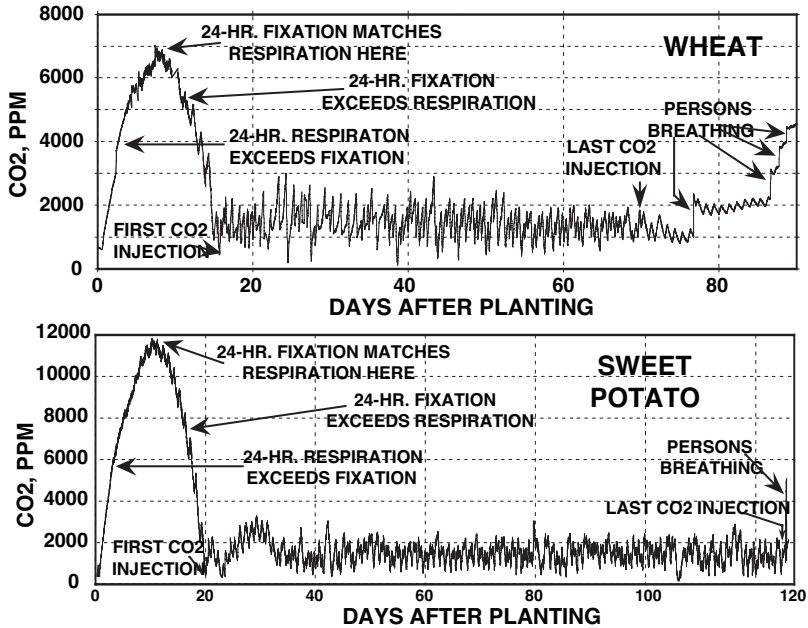

Fig. 8. $\mathrm{CO}_{2}$ in Laboratory Biosphere during wheat and sweet potato experiments. $\mathrm{CO}_{2}$ initially rises while the new plants are very small then falls rapidly as they grow larger and photosynthesis increases. 58 injections maintain $\mathrm{CO}_{2}$ levels for wheat (days 15 - 69) and 91 injections for sweet potato (days 20 $-124)$.

to balance photosynthesis and respiration for human life support must be achieved. A balanced system cannot be assembled without a detailed understanding of the behavior of its most important components including food crops as they progress from seedlings to harvest.

Recent successive experiments in Laboratory Biosphere with first wheat and then sweet potato crops provided data on total biomass and edible food production, water evapotranspiration rates and the fixation rate of carbon dioxide at every stage of crop growth. Significant differences between these two crops were observed (Dempster et al, 2005). Figure 8 shows the $\mathrm{CO}_{2}$ concentration during each experiment.

While these $\mathrm{CO}_{2}$ concentration curves may seem very similar, important differences are revealed by a study of rates of net fixation and respiration determined by the first time derivatives taken at hundreds of selected segments of each curve. The net fixation rates are presented in Figs. 9 and 10. Fixation is represented as a negative number and respiration as positive which enables both processes to be shown on the same graph without overlap of these opposites.

This analysis reveals very noticeable differences between the two crops. Wheat rapidly increases net fixation rates to a maximum circa days 25 - 30 and then net fixation decreases almost as rapidly to a definite end point just before harvest circa day 80 . This corresponded with the qualitative observation that the plants became brown and dry with fully developed seed while vegetative growth had ended at about the same time. In contrast, net fixation by sweet potato increased, not as rapidly, up to about day 40 and then with some variations continued at roughly the same rate until the arbitrarily exercised harvest at day 126 . Vegetative growth was 


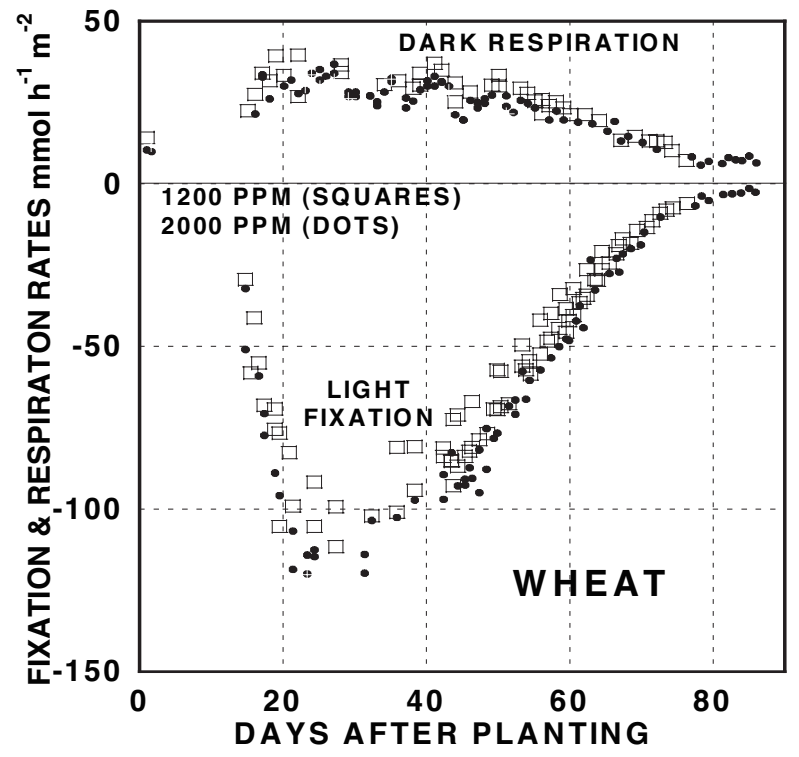

Fig. 9. Fixation and respiration rates for wheat at $1200 \mathrm{ppm}$ (squares) and 2000 ppm (dots).

evidently still unabated and may well have continued for much longer.

For both crops, many net fixation and respiration rates were determined at differing $\mathrm{CO}_{2}$ concentrations. Points are plotted for both 1200 ppm (squares) and 2000 ppm (dots) in these two graphs (Figs. 9 and 10). While

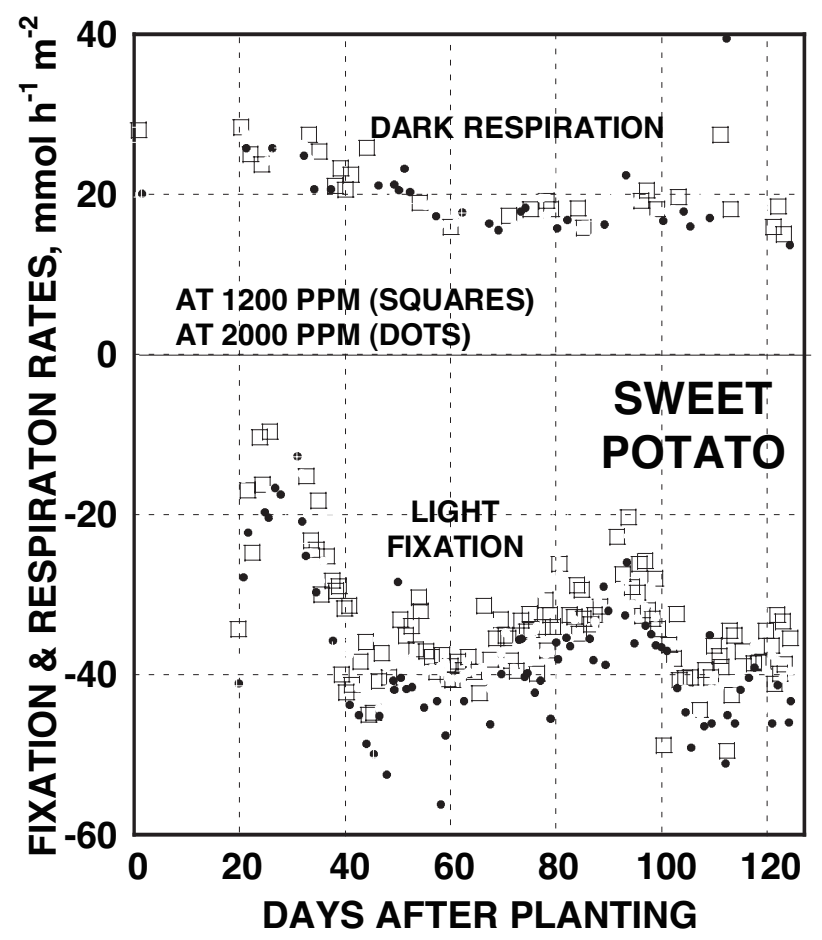

Fig. 10. Fixation and respiration rates for sweet potato at 1200 ppm (squares) and 2000 ppm (dots). there may be some isolated exceptions, it is generally seen that net fixation rates are greater at the higher $\mathrm{CO}_{2}$ concentration. This suggests that vegetative growth is enhanced with increasing $\mathrm{CO}_{2}$, at least up to $2000 \mathrm{ppm}$. These represent two of the many required building blocks of data that can contribute to assembling a complex system such as Mars On Earth®.

\section{Mars On Earth $囚$ Project}

Biosphere Foundation's Mars On Earth® (MOE) project will simulate a 4 person sustainable life support system designed for Mars. This closed system, which has a footprint of approximately $800 \mathrm{~m}^{2}$, will be used to develop space-based life support systems, such as water and wastewater recycling, food production, air purification, etc. and to develop space engineering and technology for the Mars Base. The test bed will be atmospherically closed to examine biogeochemical processes, but open to information, energy and certain material exchanges. As a modular system, the Mars Base will have the flexibility to add on chambers - hence the number humans and their length of occupation inside the system will vary depending upon the experiment protocol. In particular, the overall design will address not only the functional requirements for maintaining long term human habitation in a sustainable artificial environment, but the aesthetic need for beauty and diversity of foods which has been noticeably lacking in most space settlement designs.

Once the facility has demonstrated that a biospheric life support system is feasible and is desirable for humans to inhabit, human future in space will become a real possibility. People will realize that it is a very exciting frontier to be explored. This investigation into life support systems will not only yield data for space exploration but also information that can be used to understand and preserve the ecological health of our own planet. The goal is to produce a complete diet and to recycle all waste products including human waste from the crew (Allen and Alling, 2002; Silverstone et al. 2003).

The proposed opaque structure, designed to have 4 modular units each composed of approximately 5000 $\mathrm{m}^{3}$ (total of $20,000 \mathrm{~m}^{3}$ ), will be pressurized at about 1-2 psi above ambient. Two of the units will be used for field agriculture, each with two levels totaling $245 \mathrm{~m}^{2}$, and another with $125 \mathrm{~m}^{2}$ as a horticulture garden and utility water tank/pond storage. The fourth unit will be a $250 \mathrm{~m}^{2}$ habitat with two levels for the kitchen, office/ communication center, food processing, living quarters and Wastewater Garden for processing human waste. The agriculture/horticulture design is based on $50-70 \mathrm{~mol} \mathrm{~m}^{-2}$ $\mathrm{d}^{-1}$ of artificial light on a schedule of $14-18$ hours/day depending on crop requirements. The electrical load required to operate the lights, both for plant growth and human needs, pumps, cooling, and other technical 
Table 4 Calculation of protein \& fat from ten crops in the MOE facility based on $3000 \mathrm{kcal} /$ person/day.

\begin{tabular}{|l|c|c|c|c|}
\hline Crop & $\begin{array}{c}\text { kcal/person } \\
\text { per day }\end{array}$ & $\begin{array}{c}\text { Grams of crop } \\
\text { per day }\end{array}$ & $\begin{array}{c}\text { Protein from } \\
\text { crop per day }\end{array}$ & $\begin{array}{c}\text { Fat from crop/ } \\
\text { day }\end{array}$ \\
\hline Rice & 450 & 128.57 & 16.71 & 1.29 \\
\hline Wheat & 300 & 90.91 & 11.82 & 1.82 \\
\hline Sweet Potato & 750 & 707.55 & 7.08 & 1.98 \\
\hline Peanut & 150 & 25.68 & 6.68 & 12.33 \\
\hline Soybean & 150 & 37.31 & 2.99 & 6.72 \\
\hline Pinto bean & 300 & 87.72 & 21.05 & 0.75 \\
\hline Winter squash & 225 & 354.89 & 3.55 & 0.35 \\
\hline Beet root & 225 & 505.62 & 5.06 & 0.1 \\
\hline Banana & 300 & 500 & 3 & 10 \\
\hline Papaya & 150 & 576.92 & 1.73 & 0.4 \\
\hline Total & 3000 & $\mathbf{3 0 1 5 . 1 8}$ & $\mathbf{7 9 . 6 6}$ & $\mathbf{3 5 . 7 4}$ \\
\hline
\end{tabular}

equipment is estimated to be around $1.2-1.5 \mathrm{MW}$.

Potable water will be generated using methods of condensation with back up UV sterilizers for further treatment. The irrigation water will be a mix of subsoil drainage, potable water, utility water and treated wastewater. A mixing system will be available to mix the water prior to irrigation. A 28,000 liter $(7,000$ gallon) utility water tank will be included as the main water reservoir given that at any one time the amount of water that can be held in the soil may vary due to differing harvest strategies. This leaves a reserve that will be held in an open tank simulating a natural pond environment located in the horticulture chamber. The pond will simulate a rocky pool with wild aquatic ecology and will provide the drew with the aesthetic beauty of a wilderness pool. The waste recycling system will combine an anaerobic septic tank and a subsurface flow wetland plant treatment facility, technology we developed called Wastewater Gardens ${ }^{\circledR}$ (Nelson et al, 2002). The system will be able to handle 40 liters (10 gallons) per person per day with a fourday residence period at an overall area of $9.3 \mathrm{~m}^{2}$ (100 sq ft). The depth of the wetland subsurface marsh tank will be 0.6 $\mathrm{m}(2 \mathrm{ft})$. Plants will be selected for edible use such as banana and papaya trees, along with other flowering shrubs, such as canna lily and arrowheads.

The MOE diet, $3000 \mathrm{kcal}, 79 \mathrm{~g}$ protein and $35 \mathrm{~g}$ of fat per person/day, has been designed using the data and experience from Biosphere 2 and the Laboratory Biosphere (Nelson et al, in press; Silverstone et al, in press; Silverstone et al 2003; Walford 1992). While we are presently using the Laboratory Biosphere to test other MOE crop candidates, the system is designed to provide a diet that will utilize ten crops (Table 4) selected because of their proved success in
Table 5 Estimated area needed for a complete nutritional diet for the MOE 4 person crew using ten major crops. The estimates are based on Biosphere 2 yields and 50 $\mathrm{mol} / \mathrm{m}^{2} / \mathrm{d}$.

\begin{tabular}{|l|c|c|c|c|}
\hline Crop & Daily kcal & $\begin{array}{c}\text { Yield: } \\
\mathbf{5 0} \mathbf{~} \mathbf{~ o l} \mathbf{~ m}^{2} / \mathbf{d}\end{array}$ & $\begin{array}{c}\text { Yield: } \\
\mathbf{k c a l} / \mathbf{~ m}^{2} / \mathbf{d}\end{array}$ & $\begin{array}{c}\text { Area required } \\
\left(\mathbf{m}^{2}\right)\end{array}$ \\
\hline Rice & 1800 & 0.011 & 40.55 & 44.39 \\
\hline Wheat & 1200 & 0.007 & 24.38 & 49.22 \\
\hline Sweet Potato & 3000 & 0.032 & 33.69 & 88.51 \\
\hline Peanut & 600 & 0.003 & 16.32 & 36.77 \\
\hline Soybean & 600 & 0.003 & 10.64 & 56.41 \\
\hline Pinto bean & 1200 & 0.007 & 25.36 & 27.32 \\
\hline Winter squash & 900 & 0.085 & 54.32 & 16.57 \\
\hline Beet root & 900 & 0.046 & 20.45 & 44.01 \\
\hline Banana & 1200 & 0.050 & 29.64 & 40.48 \\
\hline Papaya & 600 & 0.108 & 28.68 & 20.92 \\
\hline $\begin{array}{l}\text { Salad \& } \\
\text { Greens }\end{array}$ & & & & 33 \\
\hline Totals & $\mathbf{1 2 0 0 0}$ & & & $\mathbf{4 7 8}$ \\
\hline
\end{tabular}


Results from the MOE facility will be important in demonstrating what crops can produce reliable yields and which ones should be selected for a Mars mission to produce a complete nutritional diet. The facility will also be used to determine the most efficient types of lights, optimal light levels for growth of a variety of crops, energy trade-offs for agriculture (e.g. energy required for given light intensity vs. required cropping area), capabilities of Martian soils and their need for enrichment and elimination of oxides, strategies for use of human waste products, and maintaining atmospheric balance between people, plants and soils.

\section{References}

Allen, J. (2002) People challenges in biospheric systems for long-term habitation in remote areas, space stations, moon, and Mars expeditions. Life Support Biosph. Sci., 8, 67 -70.

Allen, J. (2000) Artificial Biospheres as a model for global ecology on planet earth. Life Support Biosph. Sci., 7, 1-10.

Allen, J., Alling, A. (2002) The design approach for Mars On Earth ${ }^{\circledR}$, a biospheric closed system testing facility for longterm space habitation. American Institute of Aeronautics and Astronautics. IAC-02-IAA.8.2.02.

Allen, J., Nelson, M. (1999) Biospherics and biosphere 2 mission one (1991-1993). J. Ecol. Eng., 13, 15-29.

Allen, J.P., Nelson, M., Alling, A. (2003) The legacy of Biosphere 2 for the study of biospherics and closed ecological systems. Adv. Space Res., 31 (7), 1629-1640.

Alling, A, Nelson, M., Silverstone, S., Van Thillo, M. (2002) Human factor observations of the Biosphere 2, 1991 - 1993, closed life support human experiment and its application to long-term manned mission to Mars. Life Support Biosph. Sci., 8, $71-82$.

Alling, A., Leigh, L., MacCallum, T., Alvarez-Romo, N. (1990) Biosphere 2 Test Module Experimentation Program. In Biological Life Support Systems (eds by Nelson, M. and Soffen, G.A.) Synergetic Press, Tucson, 23-32.

Alling, A., Nelson, M., Leigh, L., Frye, R. MacCallum, T., Alvarez-Romo, N. (1993) A summary of the Biosphere 2 Test Module Research. In Microcosms and Mesocosms in Scientific Research (eds. Beyers, R. and Odum, H.T.) Springer-Verlag, New York, 1993.

Barta, D.J., Henderson, .K., Desmond, M., Henninger, D.L. (2001) Gas exchange, transpiration and yield of sweet potato grown in a controlled environment. Life Support Biosph. Sci., 7 (1), 46. [Abstract only]

Bolin, B. and Cook, R.B. (1983) (Eds.). The major biogeochemical cycles and their interactions, John Wiley \& Sons, NY, 1983.

Bohn, H.L. (1972) Soil adsorption of air pollutants. J. Environ. Qual., 1, 372-377.

Bugbee, B., Salisbury, F.B. (1988) Exploring the limits of crop productivity. 1. Photosynthetic efficiency of wheat in high irradiance environments. Plant Physiol., 88, 869-878.

Dempster, W.F. Tightly closed ecological systems reveal atmospheric subtleties - experience from Biosphere 2. Presented at COSPAR, Paris, July 2004. Adv. Space Res. [in press]
Dempster, W.F. (1994) Methods for Measurement and Control of Leakage in CELSS and their Application and Performance in the Biosphere 2 Facility. Adv. Space Res., 14 (11), 331-335.

Dempster, W.F., Allen, J.P., Alling, A., Silverstone, S., Van Thillo, M. (2005) Atmospheric dynamics in the "Laboratory Biosphere" with wheat and sweet potato crops. Adv. Space Res., 35(9), 1552-1556.

Dempster, W.F., Van Thillo, M., Alling, A., Allen, J.P., Silverstone, S., Nelson, M. (2004) Technical review of the Laboratory Biosphere closed ecological system facility. $A d v$. Space Res., 34, 1477-1482.

Frye, R., Hodges, C. (1990) Soil Bed Reactor Work of the Environmental Research Laboratory of the University of Arizona in Support of the Research and Development of Biosphere 2, In Biological Life Support Technologies, (eds Nelson, M. and Soffen, G.A.), NASA CP-3094 and Synergetic Press, Oracle, AZ: pp. 33-40.

Glenn, E.P., Frye, R. (1990) Soil Bed Reactors as Endogenous Control Systems of CELSS, In Workshop on Artificial Ecological Systems, Proceedings of Meeting in Marseilles, France, October, sponsored by DARA and CNES, 41-58.

Marino, B., Mahato, T.R., Druitt, J.W., Leigh, L., Lin, G., Russell, R.M., Tubiello, F.N. (1999) The agricultural biome of Biosphere 2: Structure, composition and function. Ecol. Eng., 13, 199-234.

Morowitz, H., Allen, J.P., Nelson, M., Alling, A. (2005) Closure as a Scientific Concept and its Application to Ecosystem Ecology and the Science of the Biosphere. Adv. Space Res., 36(7), 1305-1311.

Nelson, M., Dempster, W.F., Alvarez-Romo, N., MacCallum, T. (1994) Atmospheric Dynamics and Bioregenerative Technologies in a Soil-Based Ecological Life Support System: Initial Results from Biosphere 2. Adv. Space Res., 14(11), 417-426.

Nelson, M., Dempster, W.F., Silverstone, S., Alling, A., Allen, J.P., Van Thillo, M. (2005) Crop Yield and Light/Energy Efficiency in a Closed Ecological System: Two Laboratory Biosphere Experiments. Adv. Space Res., 35(9), 1539-1543.

Nelson, M., Allen, J., Alling, A., Dempster, W.F., Silverstone, S. (2003a) Earth applications of closed ecological systems: relevance to the development of sustainability in our global biosphere. Adv. Space Res., 31(7), 1649-1656.

Nelson, M., Alling, A, Dempster, W.F., Van Thillo, M., Allen, J. (2002) Potential integration of wetland wastewater treatment with space life support systems. Life Support Biosph. Sci., 8 (3-4), 149-154.

Nelson, M., Dempster, W.F., Alling, A., Allen, J.P., Rasmussen, R., Silverstone, S., Van Thillo, M. (2003b) Initial experimental results from the Laboratory Biosphere closed ecological system facility. Adv. Space Res., 31(7), 1721-1730.

Nelson, M., Leigh, L., Alling, A. et al. (1992) Biosphere 2 Test Module: A Ground-Based Sunlight-Driven Prototype of a Closed Ecological System. Adv. Space Res., 12(5) 151-156.

Salisbury, F.B, Dempster, W.F., Allen, J.P., Alling, A, Bubenheim, D., Nelson, M., Silverstone, S. (2002) Light, 
plants, and power for life support on Mars. Life Support Biosph. Sci., 8(3-4), 161-172.

Salisbury, F.B., Bugbee, B., Bubenheim, D. (1987) Wheat production in controlled environments, Adv. Space Res., 7 (4), 123-132.

Schlesinger, W.H. (1991) Biogeochemistry: An Analysis of Global Change, Academic Press, NY, 1991.

Silverstone, S., Nelson, M. (1996) Food Production and nutrition in Biosphere 2: results from first mission, September 1991-September 1993. Adv. Space Res., 18 (4-5), 49-61.

Silverstone, S., Nelson, M. Alling, A., Allen, J.P. (2005) Soil and crop management experiments in the Laboratory Biosphere: an analogue system for the Mars on Earth ${ }^{\circledR}$ facility. Adv. Space Res., 35(9), 1544-1551.

Silverstone, S., Nelson, M. Alling, A., Allen, J. (2003) Development and research program for a soil-based bioregenerative agriculture system to feed a four person crew at a Mars base. Adv. Space Res., 31(1), 69-75.

Walford, R.L., Harris, S.B., Gunion, M.W. (1992) The calorically restricted low-far nutrient-dense diet in Biosphere 2 significantly lowers blood glucose, total leukocyte count, cholesterol, and blood pressure in humans. Proc. Natl. Acad. Sci., 89 (11), 533-537. 